\title{
Street typology in Kathmandu and street transformation
}

The lively and pedestrian-friendly streets of the Malla period and the unique streetscape of the Rana period, including streets in planned and haphazardly developed areas, are being rapidly transformed due to unmanaged urban growth, chaotic construction and a growing number of vehicles in Kathmandu. This has destroyed the physical form, reduced social activities, increased accidents and decreased pedestrian comfort on all types of streets. These negative consequences cannot be addressed through the existing legal and institutional frameworks of the urban-development and traffic-management authorities. Even recent street improvements have discouraged pedestrian movement, degraded the streetscape and replaced public spaces with traffic. This has further con- gested pedestrians and traffic in areas that were already crowded. To reverse this trend and to enhance the qualities of traditional streets of Kathmandu, a threefold urban design strategy is essential. This will decentralise business activities from urban centres, improve transitional spaces between streets (and sidewalks) and ground-floor activities of buildings on both sides of the streets, and strictly enforce traffic management, all supported by flexible design guidelines, incentives and consensus among various stakeholders.

Keywords: street typology, unmanaged growth, traffic management, pedestrian movement, Nepal 


\section{Introduction}

The political historic periods of the Kathmandu Valley (and Nepal) are the Kirata period (prehistoric), the Lichchhavi period (first-ninth centuries), the Malla period (thirteentheighteenth centuries) and the Shah period (eighteenth century-2007); the Rana ruled from 1846 to 1951, and the Republic of Nepal was established in 2007. Early Nepalese villages (Nep. grama) located on fallow high ground in the prehistoric Kirata period expanded into administrative commercial centres (Nep. dranga) during the Lichchhavi period. These were further extended, connected by roads and fortified by gates and walls during the Malla period, leading to the formation of medieval town centres in the Kathmandu Valley (Regmi, 1965; Oldfield, 1974; Wolfgang, 1976; Malla, 1978; Slusser, 1982). The Kathmandu Valley comprises five municipalities (Kathmandu Metropolitan City, Lalitpur Sub-Metropolitan City, Bhaktapur, Madhyapur Themi and Kirtipur) and an additional 97 villages. Among the many towns of the valley, Kathmandu was further transformed during the Rana period in general and in the last six decades of modern development in particular.
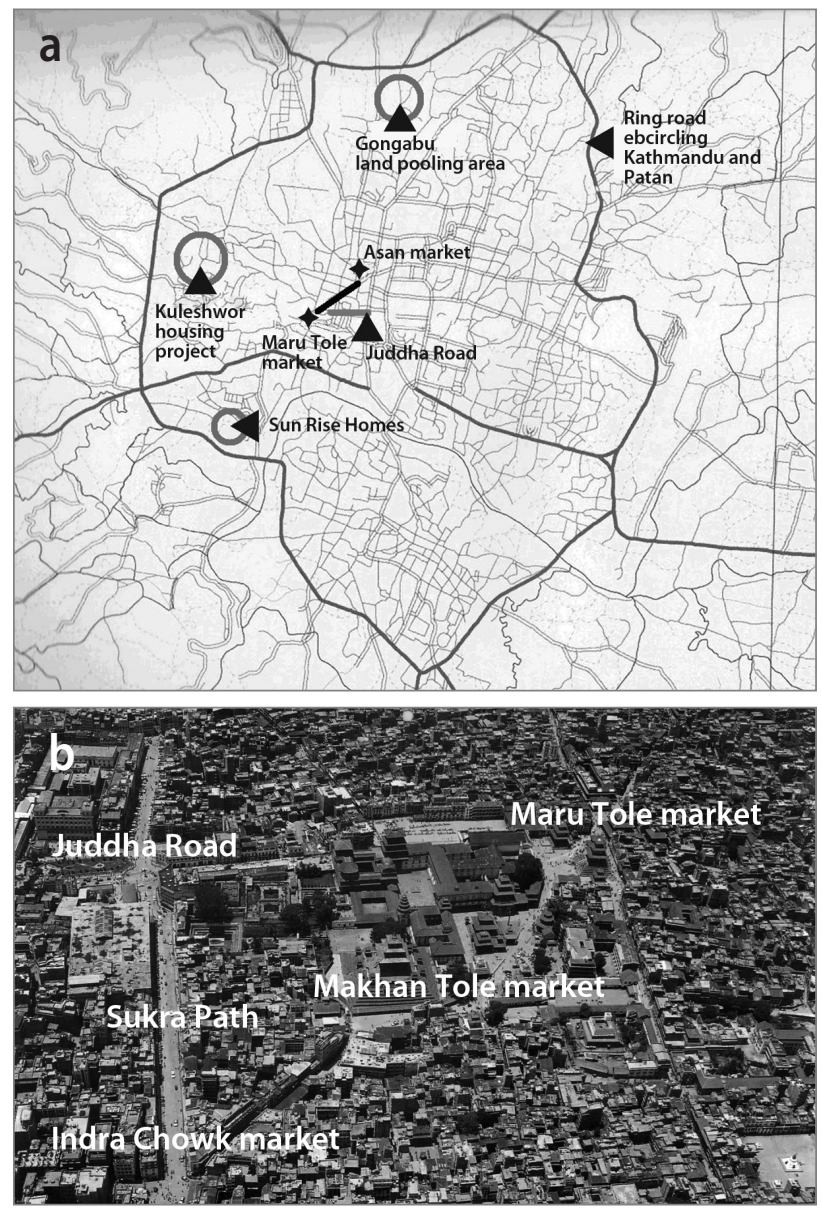

Figure 1: Combined street network including traditional streets of the Malla and Rana periods: a) Road network in Kathmandu; b) Layout of the street network in the Malla and Rana periods (source: a: Shrestha \& Pradhan, 2000; b: Weise, 2007)
Kathmandu is the administrative, socio-cultural, economic and tourist centre of Nepal as well as its political capital, and it has produced various layers of urban forms connected to the socioeconomic realities and development processes of those political periods. Expanding extensively both horizontally and vertically over $52.98 \mathrm{~km}^{2}$, the city is divided into 35 wards comprised of both planned and unplanned segments as well as old and new settlements produced by formal and informal processes. Urban streets in the historic core of Kathmandu developed before the advent of automobiles and were shared community spaces for performing multiple social and religious activities, whereas other streets in the peripheral neighbourhoods were basically the residual spaces left over after the construction of individual buildings. Some parts of the city were planned for special sites and services and through land pooling and comprehensive housing schemes implemented by public and private sectors (Figure 1).

The rapid increase in population and automobiles, and densification of the limited urban areas including haphazard transformation of buildings have created conflicts between vehicular and pedestrian movement, increased traffic jams and road accidents, and increased air and noise pollution. The earlier form and function of the streets has also changed in many ways. Against such a background, this paper explores the qualities of various street typologies and their current transformation with a fourfold objective. First, it reviews various literature on the requirements of "great liveable streets" and then identifies the salient features of the traditional streets developed in the Malla and Rana periods as well as the streets in peripheral areas. Second, it analyses the impacts of rapid urbanisation, haphazard growth of settlements and increasing traffic on them. Third, it examines the existing legal and institutional frameworks of urban-development and traffic-management authorities to check their capability to address various shortcomings. Finally, it develops some key design policies to protect the qualities of traditional streets as well as to plan future "good streets" in new urban growth areas

\section{Requirements for great liveable streets}

Streets and sidewalks cover about one-third of a city's area and have multiple functions as both paths (for access and movement) and places (as social settings). As part of the public open space network, they are the single most important urban design element that shapes the built environment, gives a neighbourhood character and regulates people's daily activity. Pedestrians' movement at the street level increases vitality and safety, and enhances commercial sustainability. Many requirements and criteria of designing a "great liveable street" are directly related to building good cities. The relationship between 
city design and transportation dates back to ancient times. The layout of roads and triumphal avenues were given high priority in ancient cities of Mesopotamia, Egypt and India. The Greeks and Romans also emphasised laying out adequate roads as an integral part of city design. In fact, as early as the first century $\mathrm{BC}$ the Roman architect and engineer Vitruvius classified the street scene into three parts - tragic, comic and satiric - and advised that streets be laid out to control the winds that bring humidity and disease into the city (Warren, 1926). According to the classic work De re aedificatoria (On the Art of Building) by Leon Battista Alberti (1404-1472), the most influential architect of the Renaissance period, noble and powerful cities should have straight streets to carry an air of majesty and greatness, whereas small towns and fortifications should have winding streets for defensive and aesthetic purposes. Similarly, the Italian architect Andreas Palladio (1518-1580) suggested segregating pedestrians from carts and livestock, and recommended building porticos on both sides of the streets in order to protect pedestrians from harsh weather. Grand avenues were a prominent feature of the Baroque cities of eighteenth-century Europe (Eisner et al., 1993).

The street generally has two generic forms. One is carved from an original block of solid material, in which the spatial volume of the street is seen as a positive form against the general background of the surrounding architecture (Rowe \& Koetter, 1978). The other concept sees the city as a parkland in which the buildings stand as three-dimensional objects as isolated sculptural forms, and the streets and other spaces flow around buildings without any shape (Cliff, 1991). Many Medieval and Renaissance streets fall into the first category, whereas the streets developed under the two city-design manifestos of the twentieth century: the new town or garden city movement (with buildings set back and an emphasis on a central green area rather than on streets) and the Charter of Athens (with streets as places for people rejected in favour of efficiency, technology and speed).

Street forms can be analysed in terms of a number of opposites such as straight or curved, long or short, wide or narrow, enclosed or open, and formal or informal, along with their scale, proportion, and contrast or connection to other streets or squares. They are defined vertically (height of buildings, walls or trees along a street) and horizontally (width of the streets). For the "great street", the Essex design guide suggests a 1:1 to 1:2.5 ratio of street width to building height (Essex County Council, 1973), whereas Raymond Unwin (1920) advocates narrow streets 6 to 9 metres wide lined by buildings three or four stories high for completeness and enclosure of the pictures framed by the streets. Baron Haussmann used the principle of the relation of building height and street width (higher buildings on wide streets and lower ones on narrow streets) in recon- structing Paris. New York's first zoning regulations were also based on the relationship between street width and building height (Marc, 1992). It is not only the ratio of street width to building height, but also the quality of buildings, especially how they relate to one another in terms of height and in the way they look, that matters a lot. Spacing of buildings along the street and the size of openings between the buildings are other important factors defining street quality.

Great streets should have multiple qualities such as accessibility, bringing people together, publicness, liveability, safety, comfort, participation, responsibility and so on (Jacobs, 1993). Great streets should be easy to get to and from, accessible to all and thus easy to record in the mental map. They are not only for exchange of services, places to do business, and linear physical spaces for public utilities and for the movement of people and goods, but they also have symbolic, ceremonial, social and political roles. Moreover, they are public showcases: places to be alone, to be private, to wonder what it was once like or what it could be like and they should always encourage socialisation and participation of people (Jacobs, 1993) so that both optional activity (jogging, sunbathing, watching or standing around enjoying life, etc.) and social activity (children at play, greetings and conversations, passive contact, etc.) can take place on the streets in addition to essential activity (going to work, shopping or waiting for a bus, etc.; Gehl, 1980). Priority should first be given to pedestrians for socialisation and public enjoyment in daily life, and at the same time drivers should also feel comfortable and safe, with a pleasing experience of the city. This requires controlling speed through various means such as narrowing streets, traffic signals and crosswalks, and speed bumps (Appleyard, 1981). Similarly, pedestrian safety and comfort can be enhanced by designing continuous sidewalks and separating them from moving vehicles by planting vegetation.

Although the need to design urban streets as a main public place rather than for vehicular speed has been advocated by many urban planners (Jacobs, 1961; Sitte, 1965; Lynch 1981; Jacobs \& Appleyard, 1987; Rapoport, 1987), until recently highway engineers have dominated the design and management of streets, mainly catering to traffic with little consideration of streets' role, form and function within the urban fabric. Great streets depend on social, cultural and economic factors (Gans, 1968), including physical environmental factors such as size and shape, microclimate, amenities and activities (Heng \& Chan, 2000). Such streets should have some designable salient features and requirements (Jacobs, 1993). After reviewing various literature on street design and urban transport management for traditional cities like Kathmandu, street typology and their transformation can be better analysed within the framework of: a) physical form and spatial char- 
acter (ratio of street width to building height, spatial definition and feeling of enclosure, legibility and permeability from surrounding areas, etc.); b) social context (public places for multiple activities, vitality, etc.); and c) users' (both pedestrians' and drivers') safety and comfort (pedestrian-friendly sidewalks, smooth vehicular movement, street amenities, safety from crimes, etc.).

\section{Street typology in Kathmandu}

\subsection{Streets of the Malla period}

Kathmandu developed on the trade routes from Kirtipur to Sankhu and from India to Tibet in the tenth century. In the following centuries it expanded on a mandala basis, with a grid pattern (deviating some 12 to 15 degrees towards the east), dividing the city into three parts - the central part (Nep. dathuwa) during the tenth to twelfth centuries, the southern part (Nep. kotwa) between the twelfth and fifteenth centuries, and the upper part (Nep. thatwa) between the fifteenth and seventeenth centuries (Figure 2). The social fabric was comprised of two basic elements: blocks of closely built three- to four-story houses clustered around courtyards and Buddhist monasteries (Nep. bahal and babil), and a network of narrow non-axial streets and pedestrian lanes including public squares and courtyards linking these blocks. These acted as figure and ground for each other.

The composition of neighbourhoods and their location, together with housing type, size and style within the town, were based on socioeconomic hierarchy. People were classified by their professions (Nep.jaata) and caste groups (touchable and socially untouchable) and their housing was zoned accordingly, with high-ranking officials, tradesmen and craftsmen (upper-caste members of the Newar ethnic group) surrounding the centrally located palace complex (the Hanuman Dhoka) and the lower caste progressively living further away. Socially un- touchable communities such as the Pode and Chyame (both of whom work as cleaners) and the Kasai (who work as butchers) were neither allowed to live within the town nor permitted to build brick and tile houses higher than one story (Burathoki, 1982). They lived outside the town wall (Oldfield, 1974) and far beyond the wall was the cemetery (Nep. Masan Ghat; Slusser, 1982). The street network and its hierarchy was also categorised based on religious functions into three types: a) streets around Durbar Square and connecting it to the main town squares (the festival procession route), b) streets linking various neighbourhoods (for the general public) and c) streets at the back of the town connected to the major river banks, especially to carry out dead bodies (funeral routes). The first two types are non-axial streets that widen and contract in various places, frequently intersecting at various locations 200 to 300 metres apart to form public squares (Kathmandu Durbar Square, market squares and neighbourhood squares) of various shapes and sizes (Figure 2b). Courtyards and pedestrian alleys link individual houses to the non-axial streets.

The houses of Kathmandu during the Malla period were unique. They had a fixed depth of generally 6 metres with vertically arranged rooms, which facilitated extension on both sides with equal building height. Common lifestyles, use of locally available building materials (sun-dried brick with mud mortar for walls, wood and mud for flooring and tiles with mud layers on wooden battens for roofs) together with similar construction (load-bearing walls) led to a uniformity in architectural styles with little variation, expressed only in quality of material, workmanship and the building façade. To give continuity to the height of adjoining houses, the eaves of the skirt-roof of a four-story house continues through at the same level as the roof of an adjoining three-story house (Wolfgang, 1976). The overall result is the creation of a singular composition with little variation in building bulk, height and rooflines, thereby strengthening the unity of many street scenes. Because streets
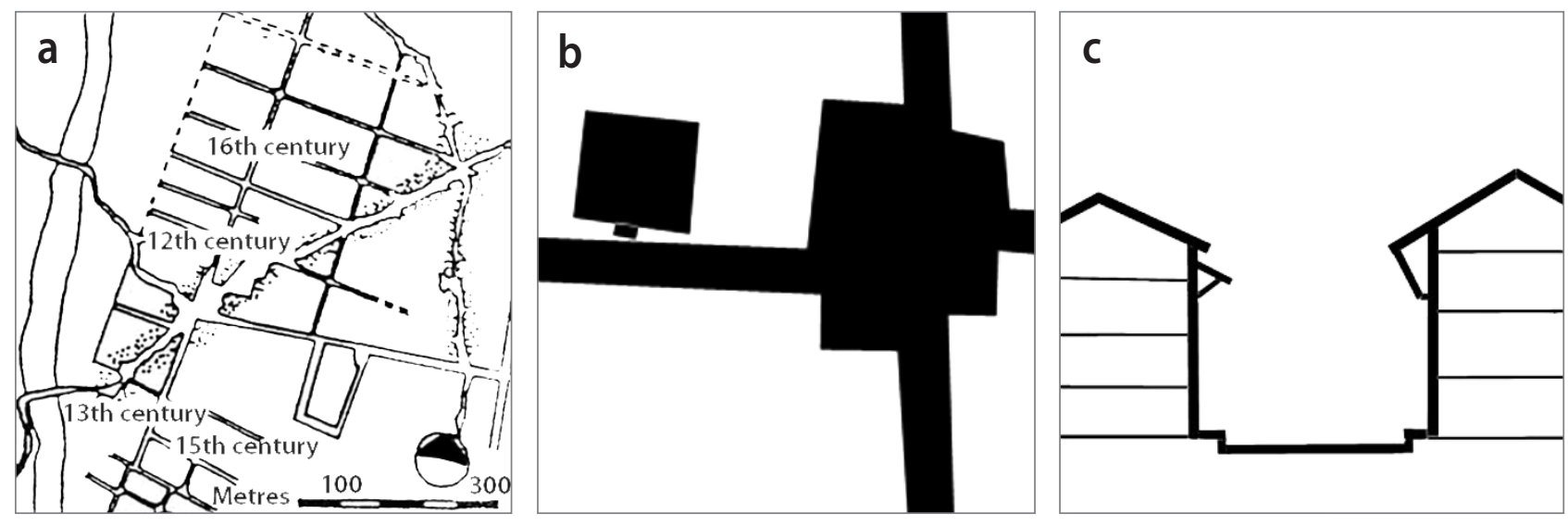

Figure 2: Salient features of Kathmandu's streets developed during the Malla period: a) The street pattern extended during the Malla period; b) The Malla period (non-axial street: vehicular alleys, courtyards, individual houses); c) Width of street: height of buildings = 1:1.5 (in general) (source: a: Shrestha \& Shrestha, 2009, b and c: illustration: Bijaya K. Shrestha). 

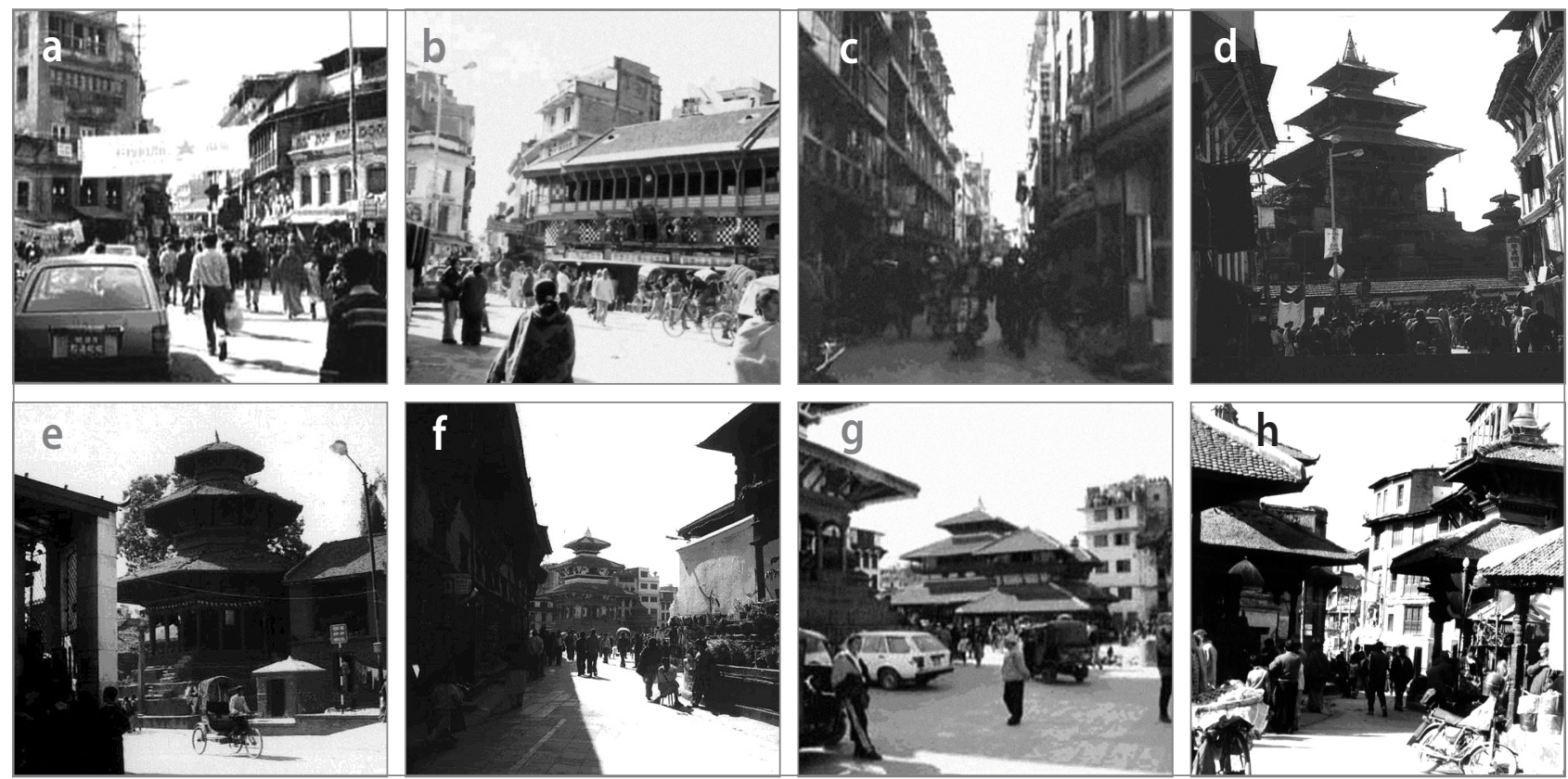

Figure 3: Sequence of views along the street from the Asan market to the Maru Tole market in Kathmandu: a) From the Asan market; b) The Indra Chowk market; c) From the Indra Chowk market; d) The Makhan Tole market (the Taleju temple); e) From the Makhan Tole market; f) From the Hanuman Dhoka palace complex; g) Basantapur Square; h) The Maru Tole market (photo: Bijaya K. Shrestha).

were generally 4 to 6 metres wide with buildings three to four stories (6.5-8.5 metres) high continuously lining both sides, the ratio of street width to building height ranges from $1: 1$ to $1: 2$, generally $1: 1.5$, thus ensuring a sense of enclosure and a human scale (Figure 2c). A specific spatial event is thus formed that creates a series of picturesque scenes. For instance, while walking down from the Asan market to the Maru Tole market, visitors feel mystery, surprise, excitement, and anticipation at the Jana Bahal shrine, the Indra Chowk market, the Makhan Tole market, the Hanuman Dhoka palace complex, and finally at the Maru Tole market due to the sudden emergence of squares, which are otherwise not visible from the street until one approaches them (Figure 3).

Closed courtyards (Nep. bahal or babil), open courtyards (Nep. chowk or nani) and public squares are part of the street network and were the focus of social settings used for multipurpose activities in daily life as well as in the festival season, including as a place to gather in the event of an earthquake. Daily activities include children playing, washing clothes and dishes, drying grain, sunbathing and socialising. The uniform flooring materials (either stone or brick) in combination with fronting all the buildings towards the squares without large breaks or gaps in continuity give these squares and residential courtyards the feeling of "outdoor rooms". They included square platforms (Nep. dabali) and rest houses (Nep. pati), and part of the public squares and courtyards were used to display images of gods and goddesses, and to perform religious dances, plays and songs (Nep. bhajan and kirtan). These were fixed places to begin, end and stop chariot processions during various festivals. Significant places such as those protected by a demon (Nep. chbwasa) and private spaces in front of the house allocated for public use (Nep. lachbi) added cultural meaning to the streets and public squares.

The narrow streets, short blocks and many courtyards and squares of Malla towns formed the backbone of friendly, interactive, safe and secure neighbourhoods. The names of streets were based on the background of that particular locality. A prefix was generally added to a main word. For instance, the Buddhist monastery of Jana Baha was named by adding jana 'people's' to the main word baha 'monastery'. Similarly, the stone fountain named Bhotahiti built by a merchant from Banepa was named by adding bhota 'Banepa' to hiti 'stone spout'. Tamo galli (Coppersmiths' Alley), representing a community of coppersmiths living in an alley, was named by adding tamo 'coppersmith' to galli 'alley, land'.

\subsection{Streets of the Rana period}

The Ranas constructed many huge palace complexes with extensive gardening at higher points in the peripheral areas of the town. Such palaces had the neo-classical style of the West. The urban blocks are enormous, filled with only a few buildings (Figure 4a). The streets are wide and straight, with sidewalks for pedestrians and a monumental character focused towards the palaces (Figure $4 \mathrm{~b}$ ). In fact, the Ranas did not destroy the old historical core, but extended the town with new urban fabrics based on new planning principles. The Singha Durbar palace complex (formerly Rana palaces, but now hous- 

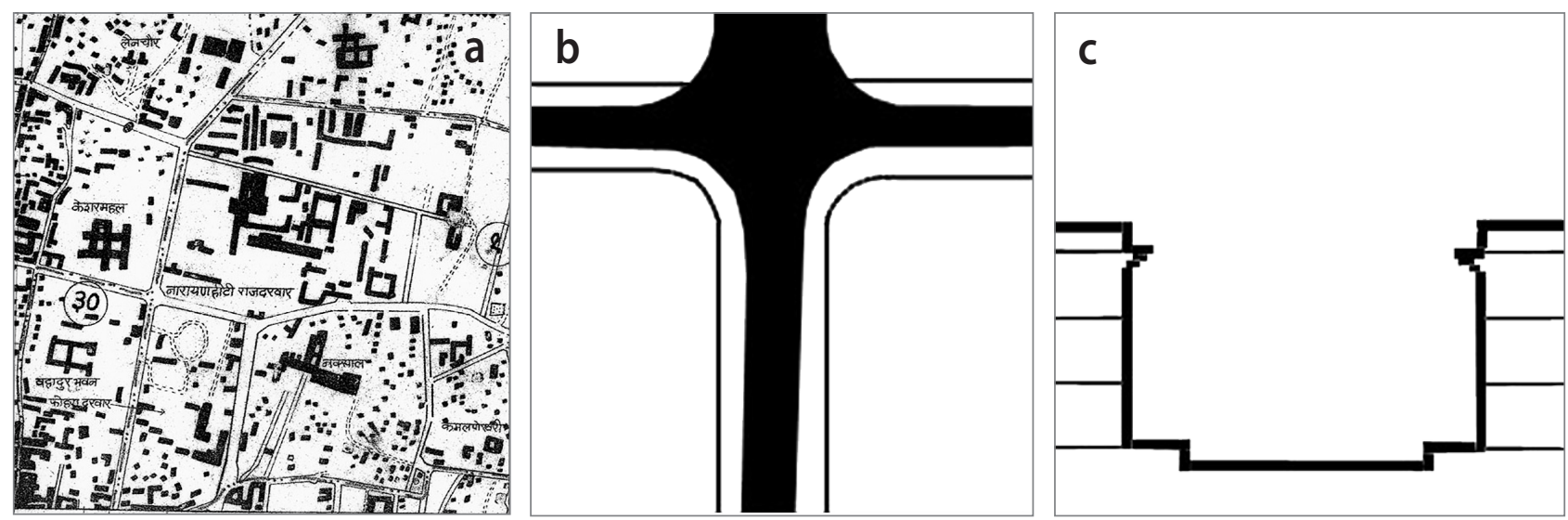

Figure 4: Characters of streets in Kathmandu developed during the Rana period: a) Wide straight road with huge urban blocks; b) The Rana period (axial street with sidewalks, palaces); c) The Rana period (Width:Height = 1.5:1) (illustration: Bijaya K. Shrestha).

ing almost all major ministries) was built during this time and it covered an area about half the size of old Kathmandu, the population of which was almost 80,000 whereas the old Hanuman Dhoka palace complex including its courtyards occupied just 1/25th of the town's space (Wolfgang, 1976)

Streets in the historic core that were damaged by the 1934 earthquake were realigned and widened, and sidewalks were added on both sides during reconstruction. In addition, identical four-story houses with white plastered walls were built on both sides of the streets. The street was later named Sukra Path after Sukra Raj Shastri, hanged for his opposition to the Rana. Likewise, another street named Juddha Road (after Prime Minister Juddha Shamsher) was also widened and sidewalks were added on both sides. In both cases, the ratio of street width (approximately $12 \mathrm{~m}$ including sidewalks) to building height of 1.5:1 has ensured a strong sense of being enclosed in an outdoor room with the sky as a firm ceiling (Figure 4c). New commercial activity introduced along this route has not only complemented the existing old trade route along the Asan market to the Indra Chowk market, but also increased pedestrian activities.

Except for the reconstructed streets of the core areas, all other streets developed during this period basically facilitated vehicular movement only, rather than acting as a place for socialisation. Nonetheless, the establishment of the fire department, public schools (Durbar School, Juddodaya Public High School, Padmodaya High School, etc.), Tri Chandra College, Bir Hospital, the Military Hospital, and the Electricity Authority around the vicinity of Rani Pokhari pool and Tundikhel Park has not only demonstrated a new style of composing public structures around urban spaces, but is also known as the beginning of development in education and health, including public safety measures against earthquake and fire. However, unlike in the Malla period, during this period streets and localities were named after persons, such as Juddha Sadak.

\subsection{Streets in haphazardly developed areas}

The third type of street and narrow pedestrian alleys are located in peripheral areas. They developed on an ad-hoc basis in a piecemeal process (Shrestha, 2010), and have different shapes, sizes and configurations without any clear hierarchy. In fact, they are the spaces left between boundary walls of private houses, after constructing buildings in the best locations at the site. They also act as "no man's land" or wasteland, used for dumping leftover construction material or household waste (Figures 5a \& 5b). Such streets are often unpaved and lack drainage and sewer lines and sidewalks. Because the architectural character, bulk and volume, including the heights of the buildings on both sides of such streets, are different, a volumetric definition and a sense of enclosure is not created (Figure 5c). Unlike in the streets in the historic core, one does not feel surprise, excitement and sequential picturesque scenes while walking on these streets. Different treatments of the "transitional space" between the ground-floor shops and the front of the street (or sidewalk) for individual buildings (continuous steps, a few steps and then wide landings, direct access from the street, etc.) have created inconvenience for shoppers and pedestrians, and slowed vehicular movement. Such streets do not encourage people to spend time outside and do not facilitate social and commercial encounters and exchange.

Walking along these narrow streets/alleys is dangerous and inconvenient not only due to a lack of pedestrian-related amenities but also because of their layout, which is not accessible to all and difficult to find and go to, often isolated from people's activities areas. During rainy seasons, these streets are full of mud and waterlogged, making pedestrian movement difficult and in some cases impossible. Neither fire engines nor ambulances can drive on such streets, thus making large part of the settlement areas vulnerable in the event of natural hazards as well as in emergency situations in daily life. 


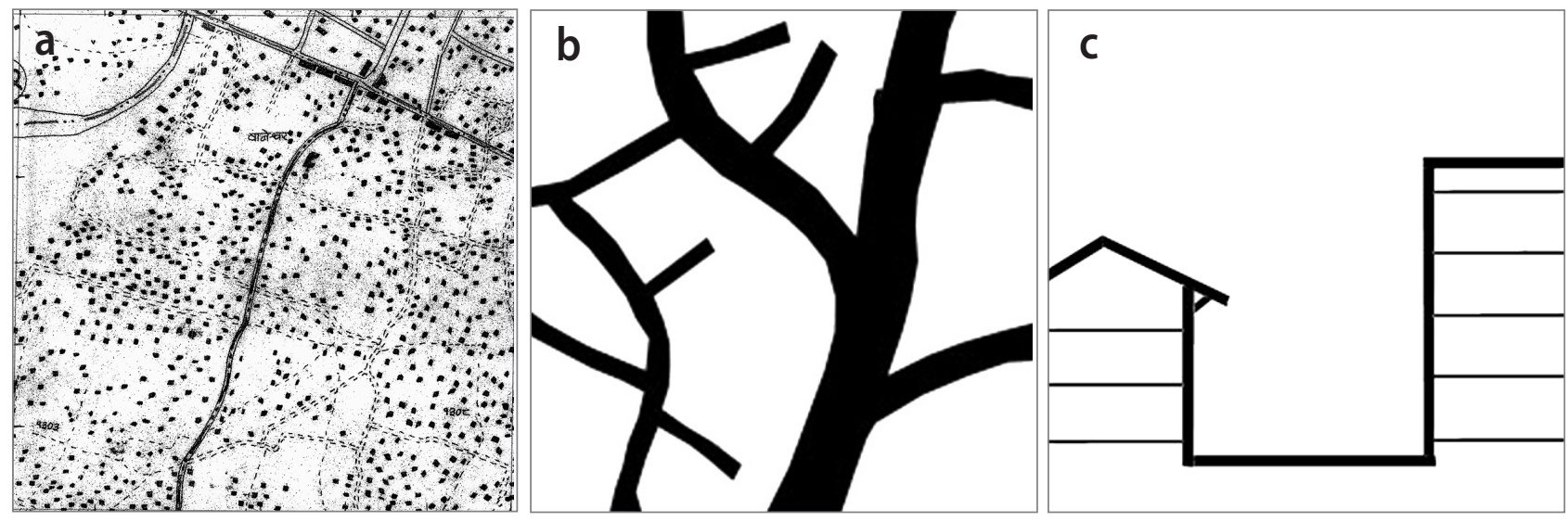

Figure 5: Characters of streets developed in post-Rana period, particularly in residential neighbourhoods: a) Formless streets; b) The post-Rana period (vehicular street, alleys, individual houses); c) Modern street without form and shape (illustration: Bijaya K. Shrestha).

\subsection{Streets of the planned urban areas}

The government of Nepal planned some residential neighbourhoods through the site-and-service program in the late 1970s and the land-pooling program in the late 1980s. The private sector's involvement was also acknowledged after enactment of the 1997 Joint Apartment Act, which was approved in 2002. The Kuleshwor Housing Project (KHP) was developed on 26.5 hectares (522 ropani) of land in 1977 for civil servants working in the government that did not have a house or land in Kathmandu. The Kathmandu Valley Town Development Committee implemented the Gongabu Land Pooling Project (GLPP) in 1986 on 14.2 hectares (280 ropani) of land (Department of Housing and Urban Development, no date). Sun Rise Home (SRH) at Balkumari was developed by the private sector on 2.3 hectares ( 45 ropani) of land (Oriental Construction and Development, no date). Although all of these developments were basically residential neighbourhoods, there is variation in the size and shape of the urban blocks, the number of buildings within the blocks, street patterns and their intersections (Table 1). Despite the fact that the KHP project area is nearly twice as big as that of GLPP, the number of urban blocks and intersections is less than that in GLPP.

In the first two cases, development was limited to recombining irregular lots into regular ones and providing vehicle access to each property. The plot configuration, street network layout and provision of infrastructure were project-specific because planning standards and guidelines did not exist. In fact, the plot size was first defined, which dictated the entire layout plan. As a result, the street network in these neighbourhoods has become the spaces left over after developing serviced plots. Hence, the intersection network itself lacks a well-defined hierarchy and these intersect poorly, with insufficient space for turning vehicles. Finally, there was no concept of urban design by integrating land development and building construction. Because the construction of individual houses is not regulated, there is no trace of street-wall formation, unity in elevation and control of building height, and hence no volumetric definition and sense of place. The absence of sidewalks and public open spaces within specified intervals makes these streets less useful for socialising. In addition, ineffective links to the public trans-

Table 1: Comparison of street characters in three planned residential neighbourhoods.

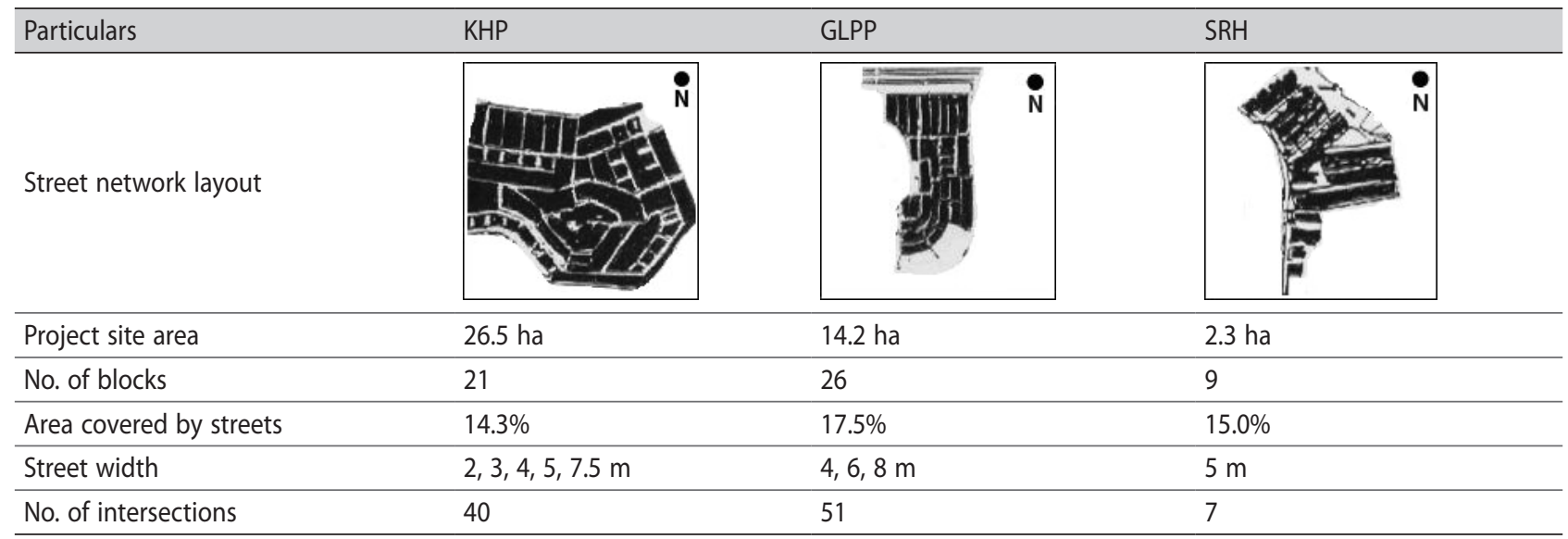

Source: Department of Housing and Urban Development (no date); Oriental Construction and Development (no date). 

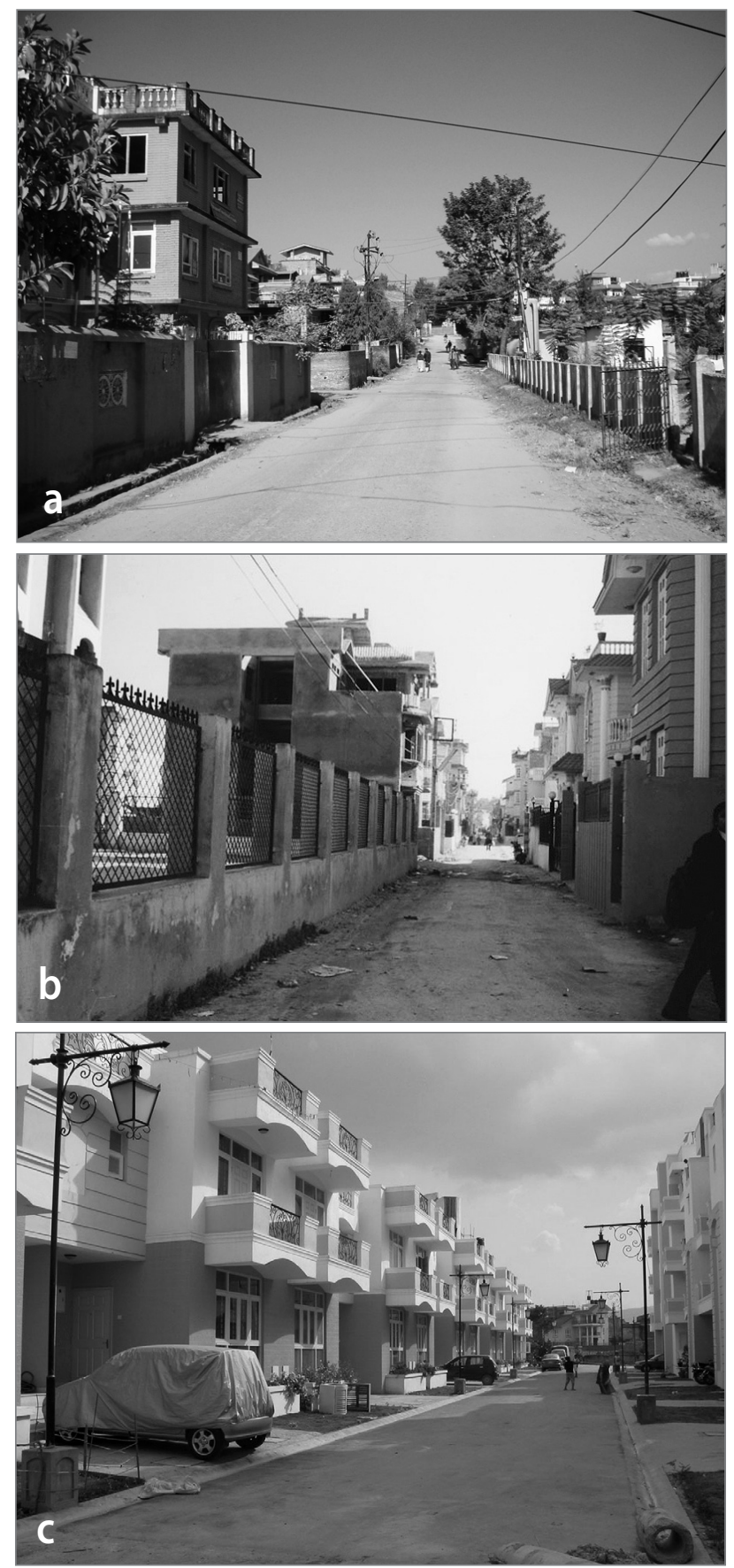

Figure 6: Characters of streets in planned residential neighbourhoods in Kathmandu: a) The Kuleshwor housing project (1977); b) Gongabu land pooling (1988); c) Sun Rise Home (2003) (photo: Bijaya K. Shrestha).

port route, a minimum number of shop fronts along the streets and lack of provision to protect pedestrians from the sun and rain also make these streets less pedestrian-friendly (Figure 6). In short, the quality of streets in these planned areas is no different from streets in areas with haphazard growth. The interesting design of individual units with uniform construction set back at SRH has failed to produce a legible residential landscape due to repetition of the standard unit in a row on both sides of the streets without any reference point. The dwelling units at SRH are mostly two to three stories high and oriented on a north-south axis. This is climatically ineffective because almost all the rooms have one side window only and many spaces (dining rooms, lounges or staircases) have no direct light or ventilation.

\section{Impacts of rapid urbanisation and the growing number of vehicles on Kathmandu's streets}

A combination of both the "pull" factor of urban centres and the "push" force in rural regions has caused enormous population migration to Kathmandu, resulting in annual population growth of $6 \%$ compared to the national average of $2.1 \%$. To accommodate the ever-increasing population and their socioeconomic activities, the compact medieval town of Kathmandu has been rapidly transformed through "high-rise high-density" (re)development in the historic core area without respecting the old fabrics and "low-rise low-density" urban sprawl in the peripheral agricultural land, irrespective of basic amenities, land-use regulation and the zoning system. In the early 1950s and the 1960s, low-density linear ribbon development without adequate infrastructure services took place along the streets connecting the historic core to numerous Rana palaces (Department of Housing and Physical Planning, 1969). This spread out further at intersections on the Ring Road (built in the mid-1970s) and arterial roads such as Balaju, Maharajgung and Jawalakhel by the 1970s and 1980s. Such a trend has continued unabated to today, extending the unregulated development in inland agricultural areas served by pedestrian alleys and beyond the city limits into the adjoining Village Development Committees (VDC), including low-lying floodplain areas. Except for a few pockets of planned areas, most of urban Kathmandu has been developed through an informal process, in which individual households arrange land on their own initiative, create street or path access and other services to the site through individual or neighbourhood efforts and build houses entirely by themselves, using their own labour or directly employing construction labour by paying on a daily basis and finally mobilising all necessary resources by themselves. This in turn has created a new demand for urban streets and public transportation. However, there is no proportionate construction of new urban streets compared to the growing rate of automobiles and population.

The number of vehicles is growing at a rate of $12 \%$ annually in the valley. This growth is highest in the case of privately owned vehicles such as motorcycles and small cars. Out of a total of 472,795 vehicles registered in Nepal by the end of fiscal year 2004/2005, 56\% (274,805 vehicles) were registered in the Bagmati Zone, most of which are used in the Kathmandu 


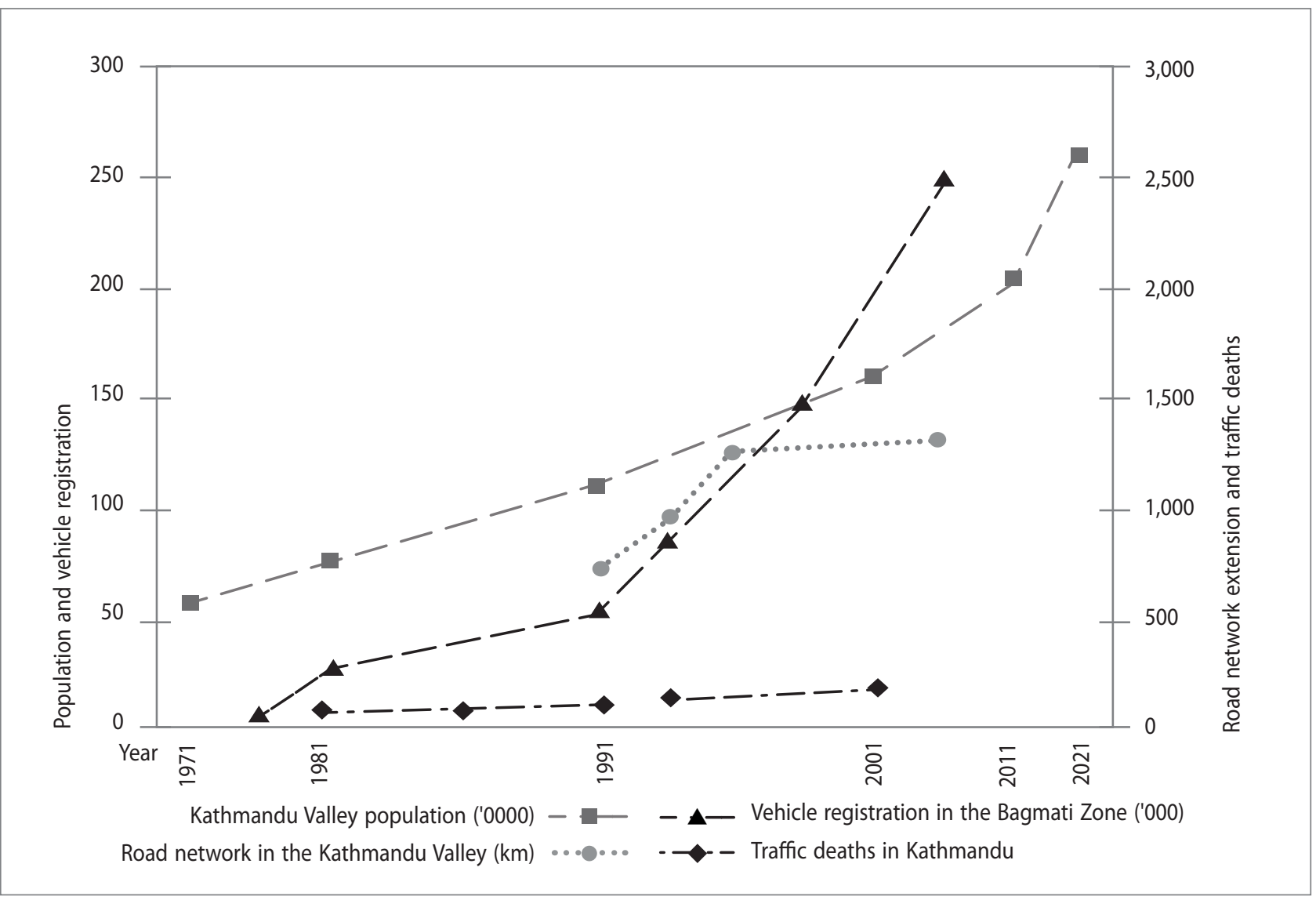

Figure 7: Growth of population and vehicle registration, including road-network construction (Source: Central Bureau of Statistics, 1972, 1982, 1992; Japan International Cooperation Agency, 1992; Kathmandu Valley Town Development Committee, 2000; Department of Roads, 2001; Department of Traffic Management, 2001).

Valley. This number is almost double the capacity of the road. If $80 \%$ of these vehicles (i.e., 219,844) were used on the valley's $\operatorname{road}(1,319 \mathrm{~km})$ at one time, each automobile would have only $6 \mathrm{~m}$ of space. About $70 \%$ of vehicles constitute two-wheelers. Low-occupancy cars dominate the road, reducing the speed to a little as $20 \mathrm{~km} / \mathrm{h}$ on inner roads and $40 \mathrm{~km} / \mathrm{h}$ on the Ring Road (Japan International Cooperation Agency, 1992). Vehicle emissions due to the increasing number of cars, lack of maintenance and poor transport management alone account for $38 \%$ of total $\mathrm{PM}_{10}$ concentration in the valley (Gautam, 2006). This has caused respiratory diseases such as childhood bronchitis, chronic bronchitis and asthma attacks. The number of patients for chronic obstructive pulmonary disease at the Patan hospital tripled from 1985 to 1991 . The cost of morbidity resulting from $\mathrm{PM}_{10}$ was found to be NPR 180 million and total health damage to be NPR 210 million. It is estimated that NPR 0.5 billion per year in tourism revenue is lost due to air pollution in the Kathmandu Valley. According to the Kathmandu Valley Traffic Police, 67\% of all types of accidents in the three principal cities of the valley (Kathmandu, Lalitpur and Bhaktapur) involve pedestrians, for whom the casualties are as high as $36 \%$, followed by $22 \%$ for motorcycle riders and 10\% for cyclists (Kathmandu Valley Traffic Police, 2001).
In nutshell, the multimodal transportation system (buses, vans, cars, motorbikes, bicycles, and pedestrians) using the same limited road, the increasing number of vehicles (with the majority being poorly maintained old vehicles), the use of low-quality fuel (mixed with kerosene) and the poor condition of the road networks have all increased traffic jams, congestion, accidents and various street crimes (Figure 7).

Failure to regulate rapid urbanisation, haphazard urban growth, building transformation, and the growing number vehicles in Kathmandu has numerous negative effects on the form and function of various street typologies. First, the vertical division of traditional buildings and haphazard renovation and reconstruction, including variations in building setback and plinth level, has destroyed the earlier ratio of street width to building height, the singular composition of continuous street walls, volumetric definition and the unity of the street scene. Buildings of varying shape, size, bulk, and height, including different architectural styles and building materials, often do not match the adjacent buildings and the surrounding environment, and this has created a chaotic streetscape without any sense of place (Figure 8). 

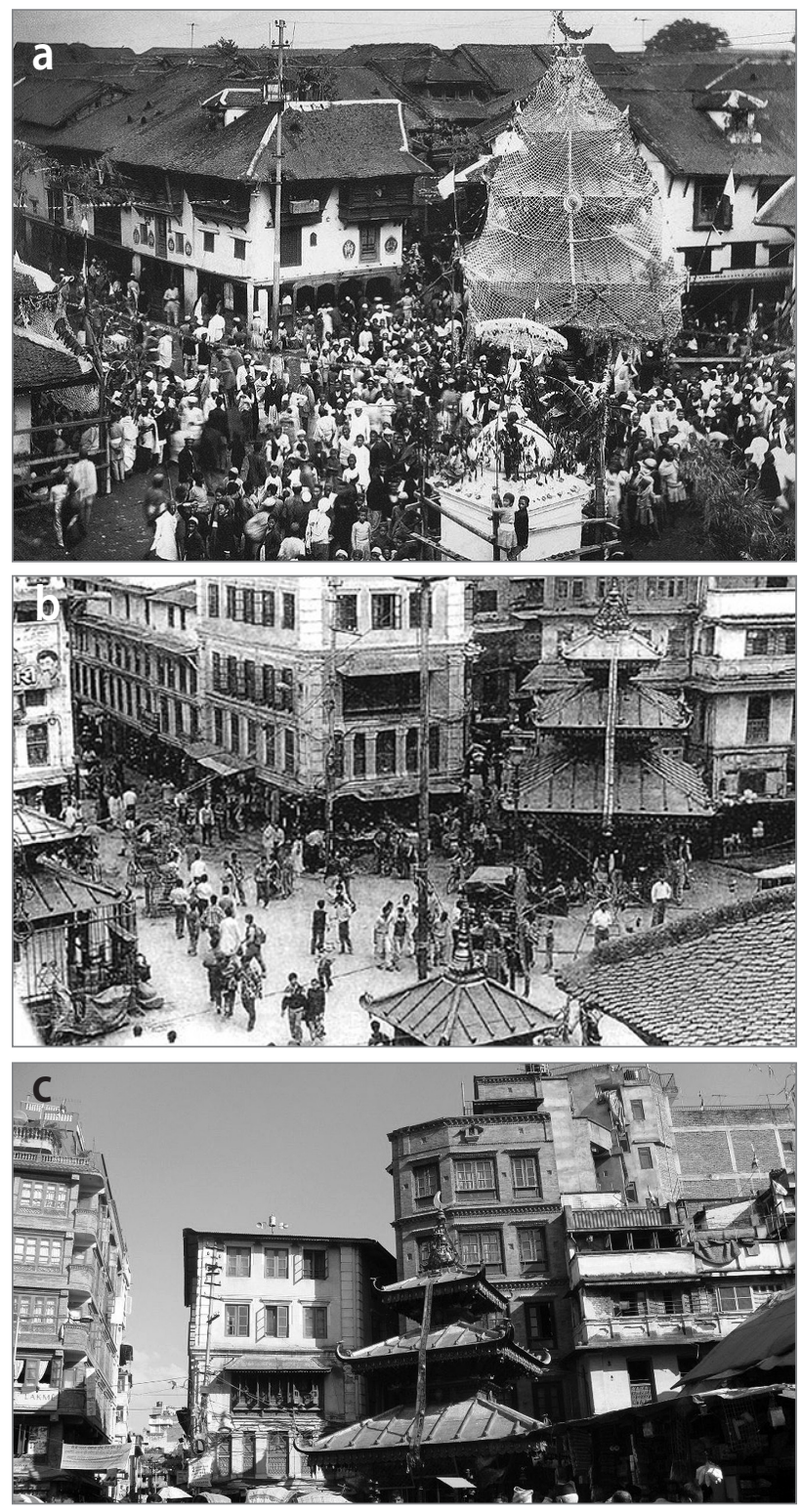

Figure 8: Transformation of streets and squares due to change in building facades and increase in vehicular movement: a) Asan square in 1920; b) Asan square in 1998; c) Asan square at present (photo: a and b: Dirgha Man Chitrakar; c: Bijaya K. Shrestha).

The haphazard addition of floors on the unifying buildings of Sukra Path and new construction on Juddha Road have destroyed the earlier feeling of enclosure (Figure 9). In other cases, the ratio of width to building height is not within the desirable limit and hence there is no sense of enclosure and street definition. Increasing buildings' height through the addition of floors or new construction together with the general practice of projecting floors from the second floor onwards has reduced light and ventilation on the streets. In addition, such structures are highly vulnerable to earthquakes and fires (Shrestha, 2002).

Second, commercialisation of spaces that are even located inside the courtyards has increased building density and vehicle use, leading to the conversion of public squares, residential courtyards and Buddhist monasteries - which were important elements of the Malla street system used for multipurpose activities - into parking lots, garbage dump sites and places where strangers gather. Historically significant Son square and the Te Bahal area, as well as other courtyards and squares, are being used for parking (Figure 10). This situation has further worsened because many water conduits have stopped functioning and numerous rest houses (Nep. pati) attached to monasteries (Nep. viharas) and squares have been encroached upon, disappeared or been demolished.

Third, walking down these streets has become hazardous now. The smooth flow of pedestrians and their safety has been challenged in many ways. The absence of well-defined continuous sidewalks has forced pedestrians to share the same narrow, poorly laid-out streets with traffic. Street hawkers haphazardly occupy the sidewalks to sell various types of goods, many shop owners occupy the sidewalk or street in front of their shop to display goods, and people shop directly from the street; all of this has reduced convenience and efficiency for pedestrians and also increased the danger of accidents. In addition, the haphazard positioning of electric poles and the general practice of using the same poles for electrical, telephone, and television lines has significantly increased the risk of electric shocks to pedestrians.

\section{Recent street improvement work}

Many street-improvement projects carried out under the $\mathrm{Mu}$ nicipal Infrastructure Improvement Project (MIIP) since 1994 and the recently completed Kathmandu Sustainable Urban Transport Project (KSUTP) study with financial support from the Asian Development Bank (ADB) have focused on vehicular movement and drivers' convenience rather than pedestrian comfort, convenience and safety. First of all, work to widen streets around Tundikhel Park and Keshar Mahal palace by reducing sidewalks (and public open spaces) has in fact encouraged new commercial activities and more traffic by creating bottlenecks at various intersections, but has discouraged pedestrian flow, forcing them to use vehicles for even short trips. The segregation of pedestrians and automobiles with an emphasis on the latter by constructing wider and larger streets is anti-pedestrian and anti-urban. Second, construction of high-density commercial complexes without considering street capacity and the use of adjacent buildings in already congested historic core areas such as Putali Street has not only aggravated the problem of parking and traffic chaos, but has also broken down the continuous street walls, unity in street elevation and smooth pedestrian flow on the sidewalk (due to underground vehicle access from the street). Third, numerous new pedestrian overpasses in various locations on the one-way 
route around Rani Pokhari pool and Tundikhel Park have separated the traffic in one direction, but created more conflicts on other sides of the intersection because one must either make a U-turn or cross a two-way street without a crosswalk while navigating through public transport at various locations. Senior citizens, children and people with luggage or children have found it inconvenient to climb up and down the steps to cross the narrow streets. Vendors and beggars occupying various parts of the overpasses have further aggravated the situation by not only making pedestrian movement difficult but also by increasing chances of thefts, pick-pocketing and other crimes. The new overpasses have not only blocked the background silhouette but have also affected street-level pedestrian activities. Similarly, various measures proposed in the KSUTP study also have many weaknesses. First, sustainable urban transport for Kathmandu can never be achieved by limiting the study in Kathmandu with only a focus on traffic and little consideration of the street's socio-cultural and pedestrian function. Despite the ADB's requirement for urban designer input, no professional urban designer was involved in this project. As a result, the study has not only failed to see urban transport from the perspective of land use and housing density changes within the context of the entire Kathmandu Valley, but has also lost the opportunity to incorporate pedestrians' diverse needs. Failure to respect "professional expertise" has derailed this project in understanding the essence of the program and thus taken the wrong direction from the very beginning. Second, the approach of facilitating vehicle traffic by widening streets, relocating public transit stops, creating one-way traffic, building pedestrian overpasses, and replacing old three-wheeled vehicles with minibuses was also implemented in the valley in the past, which briefly provided some relief at the cost of pedestrians' comfort, convenience and safety. Past experience reveals that such a myopic approach on the one hand, and little control over building construction and use on the other hand, invited more vehicle movement, thus creating traffic jams, noise and air pollution, and more accidents in the long run. Because less than $10 \%$ of the population own vehicles in the valley, the majority of the population walks for short trips. Third, proposals such as a bus station and car park on the west side of Tundikhel Park, redeveloping the old bus park and city hall, underground car parking and multiple commercial complexes at the Social Welfare Council and along the riverfronts might be feasible from a highway-engineering perspective, but they are a disaster from the urban-design point of view. Such acts will invite more vehicles, discourage pedestrian movement, and destroy the existing social fabrics and above all are not preferred options for this earthquake-prone valley. Fourth, urban transport is more like "social and cultural issues" when it comes to implementation. Replacing minibuses and three-wheelers with a single large bus, shifting bus stops and transport routes, and encouraging the use of public transport as opposed to mo-
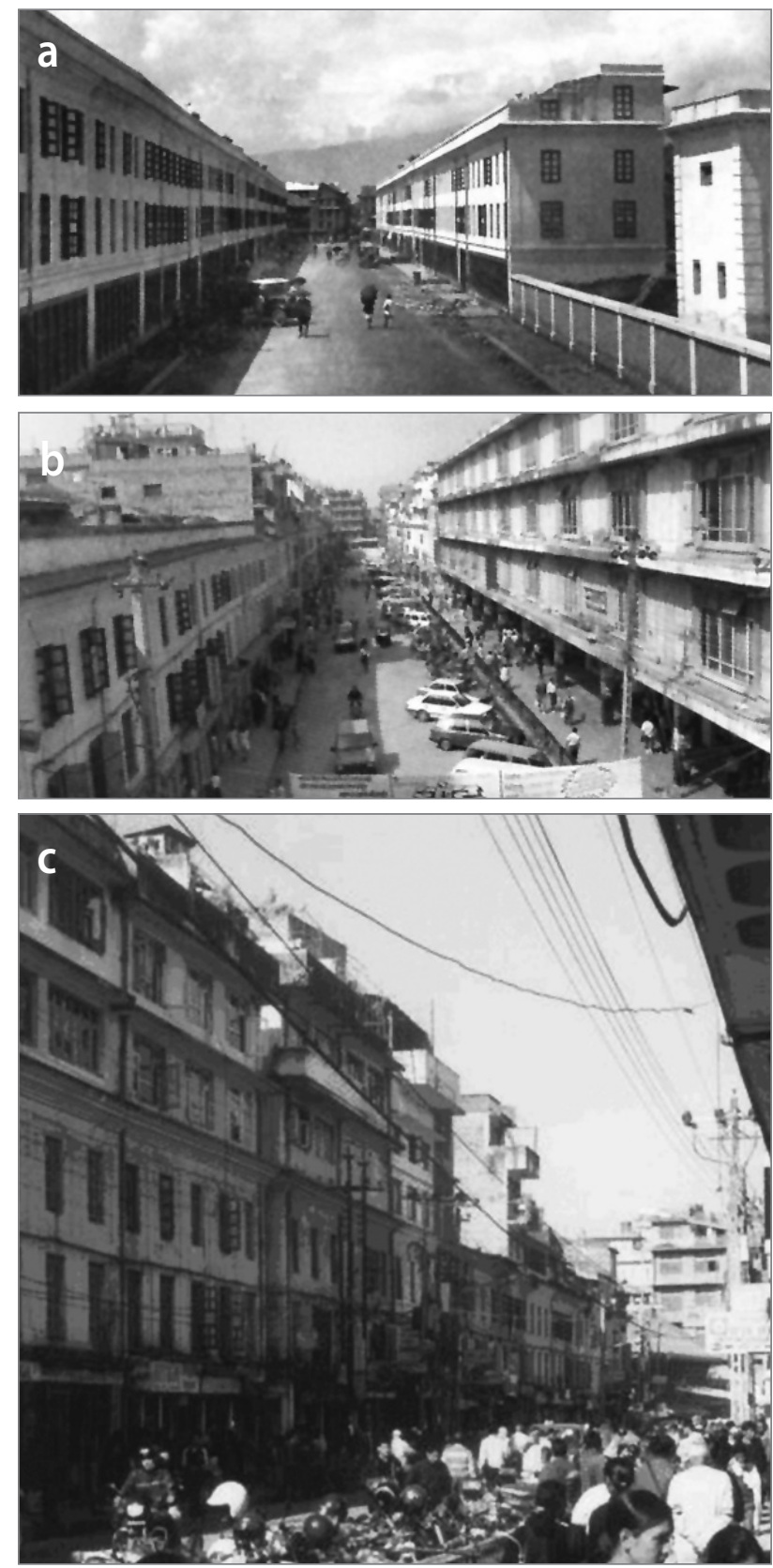

Figure 9: Destruction of Sukra Path, built by the Ranas during the 1940s: a) Rana-built Sukra Path in the 1940s; b) Sukra Path in 1992; c) Sukra Path in 2003 (Source: a and b: GTZ \& UDLE, 1995; c: photo: Bijaya K. Shrestha).

torbikes and cars have academic merit with little perspective in practice due to the lack of surveys to check the trip these routes create (a function of locational activities and density), people's willingness to use public transportation and their willingness to pay an extra fare for improved services. Most public transportation routes in the valley cannot accommodate large buses due to the narrow width and haphazard "transitional spaces" between sidewalks (if they exist) and activities on the ground floor of the buildings on both sides of the streets. The social perception of higher-status car owners and lower-status bicycle users has discouraged many people from using bicycles. Fifth, 

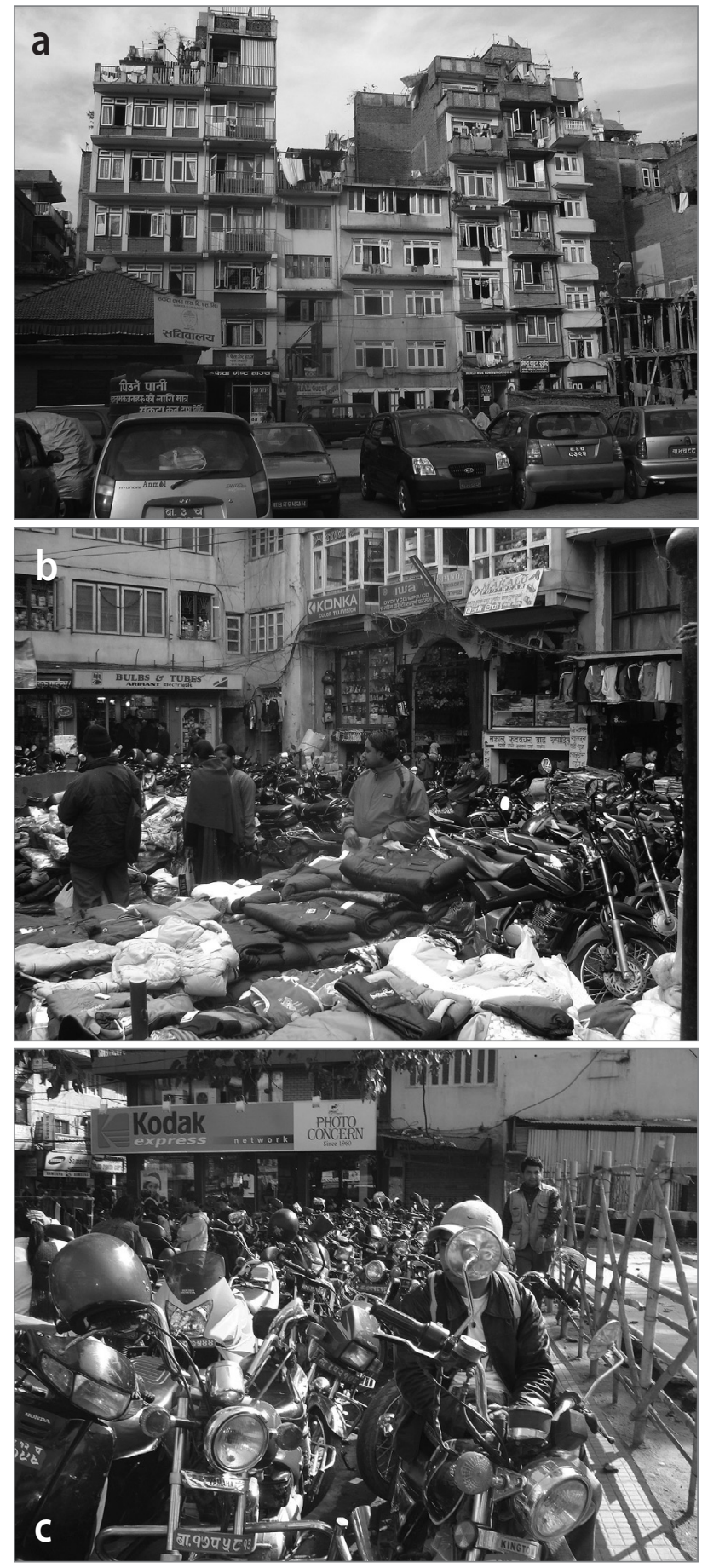

Figure 10: Community courtyards and public squares being converted into parking lots: a) Te Bahal religious courtyard; b) Community square at Pyukha Tole; c) Public square on New Road (photo: Bijaya K. Shrestha).

this study has shed little light on various non-technical factors that are responsible for not implementing many past proposals with similar recommendations. Some non-technical factors such as a lack of political willingness, duplication of duties and responsibilities among various agencies, various acts, and a culture of ignoring traffic rules and encroaching on streets and sidewalks in various ways should all be addressed first for smooth implementation of these recommendations.

\section{Legal and institutional framework}

The design of urban streets and their management should be viewed from a broader perspective within the framework of urban transport, land use and housing density. Land-use planning, urban design, transportation and traffic management are inseparable to achieve great street design. However, this is not apparent in the current legal and institutional framework. First, the needs of street design in newly planned areas and of conservation of the traditional streetscape in the historic core area are yet to be realised. Numerous government institutions responsible for urban development have overlapping jurisdictions and are working with little coordination and cooperation. However, it is not clear who is responsible for planning, designing and managing the public spaces between the buildings. Various treatments in terms of design and materials in the "transition spaces" between the streets and the ground floor shops of individual buildings remain unchecked, thereby creating a chaotic streetscape and creating inconveniences for street users. The absence of a clear government policy on land development and infrastructure provision, plus the lack of trained manpower, have reduced the scope of good street layout even in planned areas. The local real estate companies neither register their companies with the government nor obtain approval for their land development plans from the Town Development Agency. As a result, the unprincipled plot division and street layout by the private sector continues unabated. Moreover, the Department of Archaeology and other non-government organisations working in heritage conservation are basically concerned with protecting and renovating individual structures such as old palaces, temples and so on rather than preserving the traditional streetscape and neighbourhood characters. Second, the existing building bylaws, the only legal vehicle for regulating construction, are not adequate to control activities such as rapid densification, the haphazard destruction and renovation of traditional buildings, occupancy changes in buildings and so on that are destroying the streetscape. These bylaws are also unable to enhance the street definition and unity in the street scene. The municipality of Kathmandu Metropolitan City is ineffective at enforcing even simple clauses in the bylaws such as restrictions on building heights through the building permit system and monitoring construction sites. Third, Kathmandu Metropolitan City is simply ineffective at controlling the street vendors and hawkers. No organisation has a clear mandate to oversee the shop owners illegally occupying the public spaces in front of their shops. Adding public facilities such as dustbins, telephone booths, and other amenities to protect pedestrians from the sun and rain is no one's business. Fourth, the streets as public spaces are often used not only for vehicles and pedestrians, but quite often for public utilities such as sewer lines, water pipes, and electricity and telephone 
wiring. The lack of coordination among these public agencies is clearly visible in Kathmandu streets because one can always see excavation in the same street by different public agencies. Fifth, recent street-improvement projects prioritising traffic have disturbed pedestrian movement patterns, damaged the traditional streetscape and encouraged commercial development and traffic, thereby destroying numerous qualities of urban streets. Despite the creation of traffic congestion in Kathmandu streets, no concrete measures have yet taken place to reduce vehicle registration and manage the haphazard construction of huge shopping centres and department stores or office/commercial complexes in already congested areas.

There are many weaknesses in managing traffic as well. Responsible agencies such as the Department of Roads, Department of Transport Management and Kathmandu Valley Traffic Police have similar problems of overlapping and contradicting jurisdictions, and working with little coordination or cooperation. Constrained by financial and technical capabilities, they often blame each other for the chaotic traffic of Kathmandu streets. The Traffic Transport Management Act of 1992 empowers the Department of Transport Management to manage transport and traffic, including emission control, traffic conditions, and road accidents (Ministry of Law and Justice, 1992), whereas the Local Self Governance Act of 1999 strengthens local government's role in planning and development with little power in the urban road sector (Ministry of Law and Justice, 1999). At present, however, the traffic police play a major role in traffic management under an advisory role by the Department of Roads.

Awareness of traffic regulations is minimal. Many violations of traffic regulations by all parties are quite common. Pedestrians randomly cross the streets under overpasses, ignoring crosswalks, and people drive recklessly without sticking to a particular lane, pass on the wrong side, make U-turns ignoring other vehicles and stopping even in busy streets; all of this is common in Kathmandu. Even at the recently installed traffic-light intersections in the Maitighar and New Baneshwor areas, both drivers and pedestrians often ignore traffic signals, particularly in the absence of traffic police. To some extent, even the traffic police are not fully familiar with the new traffic-light system and managing traffic during rush hour. Enforcing traffic rules, issuing licenses and inspecting vehicles is very weak. For instance, the Traffic and Transportation Management Act of 1992 requires motorcycle riders to wear helmets and drivers to wear seatbelts, but this was not enforced until January 2003. However, drivers still do not follow this rule. The traffic police treat government, private and public vehicles differently when enforcing the rules. Finally, the observance of traffic week with its various awareness programs has little impact on the chaotic traffic of Kathmandu, not only because of the lack of continuity in such activities by the authorities, but especially because of the general attitude toward obeying traffic regulations.

\section{Conclusions and recommendations}

Based on physical form, social setting and user comfort, Kathmandu's streets can be grouped into three distinct typologies due to the socioeconomic effects of the Malla, Rana and post-Rana periods. In the Malla town, streets and public squares were the focus of socio-cultural activities. They had first priority in the town layout and acted as a positive form against the background of unified buildings. In contrast, the streets developed during the Rana period have a singular function of facilitating vehicle movement with little consideration of their social context, an approach totally opposite from that of the Malla tradition. Most streets constructed in the post-Rana period have been built on an ad hoc, piecemeal basis and without complementing the land use and built form of the settlements. Activities such as haphazard urban growth and land-use provisions, construction (mostly informal and without proper engineering) that often does not match the surrounding built environment and the growing number of automobiles have degraded all types of streets in Kathmandu. Because the legal tools are simply inadequate and ineffective and the authorities have poor capabilities, recent street-improvement projects have further reduced pedestrian spaces and thus the scope of socialisation, created discontinuity in the pedestrian network, and concentrated traffic and commercial development in already congested areas.

To protect and enhance the qualities of Kathmandu's streets, a threefold strategy is recommended. First, at the strategic and city level, it is essential to decentralise business activities from urban Kathmandu, enact regulations on land use and built form, and control population and traffic density. Second, at the local level, it is necessary to formulate street-design standards and guidelines, develop a continuous well-defined pedestrian network integrating public spaces and people-oriented activity nodes at a basic level, enforce traffic regulations with priority for pedestrians, and remove all forms of illegal occupancy of street spaces and sidewalks. Third, there must be cooperation and coordination between urban-development and traffic-management agencies. Finally, the following design policies will enhance the protection of Kathmandu's streets:

a) Design policies for streets in the historic core area

- Regulating ground-floor land use, building form and architectural style, including the transition space between the street and the ground-floor shops when redeveloping traditional buildings;

- Protecting and revitalising traditional public facilities such as rest houses (Nep. pati), water conduits, raised 
platforms (Nep. dabali) and so on, and encouraging new amenities such as street lamps, telephone booths, signage and so on;

- Giving priority to pedestrians over traffic, demarcating pedestrian spaces, crosswalks and so on in the streets, and discouraging street hawkers, on-street parking and occupation of street space by shop owners; and

- Restricting traffic at certain places during certain times.

b) Design policies for streets developed in the Rana period

- Preserving the streetscape of Sukra Path by regulating new construction and ground-floor land use;

- Providing trees to protect pedestrians from the sun and rain (for streets in front of the Singha Durbar palace complex and around Tundikhel Park);

- Installing traffic lights and crosswalks wherever possible instead of building pedestrian overpasses;

- Locating public transport stops and stations at convenient locations and connecting them to the main pedestrian movement pattern and pedestrian activity nodes; and

- Discouraging the haphazard use of signage and other advertising.

c) Design policies for streets in planned and unplanned peripheral urban areas

- Regulating new construction, especially at ground level in terms of ground-floor use and the transition between shops and streets to achieve a desirable streetscape and pedestrian comfort;

- Balancing street spaces for both pedestrians and traffic, with priority for pedestrians;

- Installing sidewalks on both sides of the street and keeping them free from street vendors, shop owners and so on;

- Connecting important public spaces and people-oriented activity nodes to the street through continuous convenient pedestrian routes; and

- Providing pedestrian amenities such as street lighting, telephone booths, street signage and so on.

Bijaya K. Shrestha

S (settlement-society-sustainability) 3 Alliance, Development Forum for Habitat, Kathmandu, Nepal

E-mail: bkshrestha@hotmail.com

\section{References}

Appleyard, D. (1981) Livable streets. Berkeley, University of California Press.

Burathoki, C. B. (1982) Jayasthiti Malla ko Sudhar. Kathmandu, Sajya prakashan.

Central Bureau of Statistics (1972) National Population Census 1971. Kathmandu.
Central Bureau of Statistics (1982) National Population Census 1981. Kathmandu.

Central Bureau of Statistics (1992) National Population Census 1991. Kathmandu.

Cliff, M. (1991) The European city street. Part 2: Relating form and function. Town Planning Review, 62(2), pp. 153-199.

Department of Housing and Physical Planning (1969) The physical development plan for the Kathmandu Valley. Kathmandu.

Department of Roads (2001) Road network in central region, Bagmati Zone and Kathmandu Valley. In: Kathmandu Metropolitan City \& The World Bank (eds.) City diagnostic report for city development strategy, pp. 115-144. Kathmandu

Department of Traffic Management (2001) Year wise vehicle population in Bagmati Zone. In: Kathmandu Metropolitan City \& The World Bank (eds.) City diagnostic report for city development strategy, pp. 115144. Kathmandu.

Department of Housing and Urban Development (no date) Land Development Program: Documentation and reviews of sites and services, guided land development and land pooling projects in Nepal. Kathmandu.

Eisner, S., Gallion, A. \& Eisner, S. (1993) The urban pattern. New York, Van Nostrand Reinhold.

Essex County Council (1973) A design guide for residential areas. Chelmsford.

Gans, H. J. (1968) People and plans. Harmondsworth, Penguin.

Gautam, C. (2006) Action plan for air quality management in Kathmandu Valley. Kathmandu, Ministry of Environment, Science and Technology.

Gehl, J. (1980) The residential street environment. Built Environment, 6(1), pp. 51-61.

GTZ \& UDLE (1995) Images of century - The changing townscape of the Kathmandu Valley, Kathmandu.

Heng, C. K. \& Chan, V. (2000) The making of successful public space: A case study of people's park square. Urban Design International, 5(1), pp. 27-35.

Jacobs, A. B. (1993) Great streets. Cambridge, MA, MIT press.

Jacobs, A. \& Appleyard, D. (1987) Towards an urban design manifesto. American Planning Association Journal, 53(1), pp. 112-120. DOI: $10.1080 / 01944368708976642$

Jacobs, J. (1961) The death and life of great American cities. New York, Random House.

Japan International Cooperation Agency (1992) The Study of Kathmandu Valley Urban Road Development. Research report. Kathmandu/Tokyo. His Majesty's Government of Nepal, Ministry of Works and Transport and the Department of Roads.

Kathmandu Valley Town Development Committee (2000) Development plan of Kathmandu - 2000. Kathmandu.

Kathmandu Valley Traffic Police (2001) Kathmandu Valley Traffic Police Report In: Kathmandu Metropolitan City \& The World Bank (eds.) City diagnostic report for city development strategy, pp. 115-144. Kathmandu. Lynch, K. (1981) A theory of good city form. Cambridge, MA, MIT press.

Malla, U. M. (1978) Settlement geography of Kathmandu Valley. Geographical Journal of Nepal, 1, pp. 28-36.

Marc, A. W. (1992) Skyscraper zoning: New York's pioneering role. Journal of the American Planning Association, 58(2), pp. 201-212. DOI: 10.1080/01944369208975794 
Ministry of Law and Justice (1992) Traffic and transport management act 1992. Kathmandu.

Ministry of Law and Justice (1999) Local self-governance act 2055 (1999). Kathmandu.

Oldfield, H. A. (1974) Sketches from Nepal. Delhi, Cosmo Publication.

Oriental Construction and Development (no date) Sunrise homes: International style living - bungalows. Balkumari.

Rapoport, A. (1987) Pedestrian street use: Culture and perception. In: Moudon, A. V. (ed.) Public Streets for public use, pp. 82-92. New York, Van Nastrand Reinhold.

Regmi, D. R. (1965) Medieval Nepal: Part 1. Calcutta, Firma K. L. Mukhopadhyay.

Rowe, C. \& Koetter, K. (1978) Collage city. Cambridge, MA, MIT Press.

Shrestha, B. \& Pradhan, S. (2000) Kathmandu Valley GIS database: Bridging the data gap. International Centre for Integrated Mountain Development, Kathmandu, Nepal

Shrestha, B. K. (2002) Reducing earthquake vulnerability in Kathmandu Metropolitan City. Development Insight, 1(2), pp. 36-41.

Shrestha, B. K. (2010) Preskrba s stanovanji v dolini Katmanduja: javne in zasebne pobude [Housing provision in the Kathmandu Valley: Public agency and private sector initiation]. Urbani izziv, 21(2), pp. 16-26 [8595]. DOI: 10.5379/urbani-izziv-en-2010-21-02-002

Shrestha, B. K. \& Shrestha, S. (2009) Transformation of traditional building stocks in the historic core of Kathmandu: Looking through the prism of culture and climate. Protibesh: Environment, Journal of the Department of Architecture, 13(1), pp. 5-16.

Sitte, C. (1965) City planning according to artistic principles. London, Phaidon.

Slusser, M. S. (1982) Nepal mandala: A cultural study of the Kathmandu Valley. Princeton, NJ, Princeton University Press.

Unwin, R. (1920) Town planning in practice. London, T. Fisher Unwin.

Warren, H. L. (ed.) (1926) Vitruvius: The ten books on architecture. Cambridge, MA, Harvard University Press.

Weise, K. (2007) Kathmandu Valley world heritage site: Integrated management plan. Paper presented at the UNITAR Workshop, 18 April, Hiroshima, Japan. Typescript.

Wolfgang, K. (1976) The traditional architecture of the Kathmandu Valley. Kathmandu, Ratna Pustak Bhandar. 